\title{
Legitimacy and the Swedish Security Service's Attempts to Mobilize Muslim Communities
}

\author{
Abby Peterson
}

\section{Department of Sociology, University of Gothenburg, 40530 Gothenburg, Sweden}

\begin{abstract}
The paper addresses how the Swedish Security Service (SÄPO) is attempting to mobilize the support of the Muslim communities in their counterterrorism strategy, together with their measures to prevent radicalisation processes among Muslim y oung p eople. Under what circumstances can we find voluntary cooperation by Muslim Swedes in the state's an ti-terror $p$ olicing ef forts and $u$ nder $w$ hat $c$ ircumstances can $w$ e expect $t$ hat $v$ oluntary $c$ ooperation $w$ ill be withheld? T he an alysis f ocuses $t$ wo i ntertwined f actors $w$ hich I ar gue inf luence v oluntary c ooperation: $t$ he $p$ otential unintended consequences of the Security S ervice's o utreach ac tivities and the link between cooperation, institutional legitimacy and procedural jus tice. It is ar gued that both the 's oft' and 'h ard' as pects of the Swedish S ecurity Service's preventive, $r$ espective $c$ ontrol a nd intelligence $s$ trategies, in terconnect $t$ o pr oduce $u$ nanticipated and $u$ nwanted consequences. The $S$ wedish $S$ ecurity $S$ ervice's outreach pr ogramme $c$ an $h$ ave the unintended $c$ onsequence that instead of c ounteracting radicalization processes, the programme, which targets p racticing Muslims as per definition potential terrorists, can very well lead to radicalization among young Muslims with experiences of misrecognition.
\end{abstract}

Keywords: Counterterror s trategies, proc edural justice, rel igious pro filing, Swedish Security Service, uni ntended consequences.

Hasisi, A lpert an d Fl ynn (2009: 180) m aintain that however s ophisticated gov ernment h omeland s ecurity is, wi th ev en a high I evel o fc ompetence $i \mathrm{n}$ counterterrorism $s$ trategies and tactics at the level of the local police, "the best plans and s trategies will only be effective if they are carried out in active partnership with the community". Nevertheless, they point out that while c ountless $s$ tudies hav e b een c onducted on the policing o f t errorism i $n$ rec ent y ears, "we k now I ittle about how $t$ he polic e mo bilize $c$ ommunities $t o$ cooperate with $t$ hem i $n$ ord er $t$ o prev ent ac ts o $f$ terrorism" (Ibid). The underl ying question posed in this article i s: Under what circumstances can we find voluntary cooperation by Muslim Swedes in the state's anti-terror policing efforts and under what circumstances can we expect that voluntary cooperation will be withheld?

Sweden has adopted an ant iterror progra mme that more or I ess c ontains the $\mathrm{s}$ ame $\mathrm{c}$ omponents as the United Kingdom's CONTEST programme. Similarly, the Swedish progra mme gi ves pri ority $\mathrm{t}$ ot he prev ent strategy, that is, the a im to prev ent rec ruitment i nto terrorist a ctivities. Ho wever, i n co ntrast wi th the UK counterterror s trategy (P oynting and Mason 200 6), Sweden has never singled out Muslim extremism, but has al ways included leftwing and par ticularly rightwing extremism. Nevertheless, in regards to their measures to $c$ ounterterrorism $s$ trategy $t$ o prev ent radi calisation processes am ong Muslim young people, and in stark

${ }^{*}$ Address c orresponding to th is auth or at th e Department of S ociology, B ox 720, Un iversity of $\mathrm{G}$ othenburg, $40530 \mathrm{G}$ othenburg, Sweden; Tel: + 46 (0)31773 4793; Fax: +46 (0)31-773 4764; E-mail: abby.peterson@sociology.gu.se contrast $w$ ith measures to $c$ ounter I eftwing and rightwing ex tremism, the $\mathrm{S}$ wedish Security S ervice is targeting faith c ommunities, i .e. prac ticing Muslims living in Sweden. By c asting a wi de ne $\mathrm{ti} \mathrm{n}$ their counterterrorism measures, the Service has introduced a 'religious profiling', which in effect risks criminalizing Muslims per se.

In order to address the res earch question posed in this art icle I a nalyse $t$ he $\mathrm{i}$ nherent $\mathrm{c}$ ontradictions imposed in the 'soft aspects' of the Swedish Security Service's "ou treach ac tivities" to i ntroduce a di alogue with Muslim communities and the Service's undeniable bread and bu tter mandate-surveillance and c ontrol. This ana lysis focuses t wo intertwined factors which I argue i nfluence $v$ oluntary $c$ ooperation: the potential unintended $c$ onsequences of the Security Service's outreach ac tivities and the I ink bet ween c ooperation, institutional legitimacy and procedural justice. I will first interrogate the 'soft as pects' of the S wedish S ecurity Service's outreach ac tivities in c onjunction w ith their potential uni ntentional nega tive $c$ onsequences $f$ or Muslim Swedes' v oluntary c ooperation in t he s tate's counterterrorism pro gramme be fore turning $t o$ the Service's ' hard as pects' o f s urveillance an d c ontrol, which can hypothetically under mine t he t rust an $d$ perceived I egitimacy of the Service, a lso I eading to non-cooperation. It is argued that bo th the 'soft' an $d$ 'hard' as pects o ft he $S$ wedish $S$ ecurity Service's preventive, res pective $c$ ontrol a nd $\mathrm{i}$ ntelligence strategies, intertwine to produce what Lasse Lindekilde (2012) c alls "i atrognic ef fects", t hat i s, unanti cipated and unwan ted consequences. The e mpirical s cope of 
the study only al lows for analytical conclusions, which point towards (tentative) causal relations between the Service's out reach ac tivities and pot ential non cooperation.

\section{THE SWEDISH STATE'S COUNTERTERRORISM PROGRAMME}

In 2010 the Government c ommissioned t he Swedish Security Service to author a report describing violence-promoting I slamist extremism in S weden, the radicalisation $\mathrm{pr}$ ocesses di scernible $\mathrm{i} \mathrm{n} v$ iolencepromoting Islamist circles in Sweden and the tools and strategies $\mathrm{t}$ hat $\mathrm{c}$ an be us ed $\mathrm{t} \mathrm{o} \mathrm{c}$ ounter radi calisation (Violence-promoting Islamist extremism in Sweden, 2010). In $t$ his report $t$ hey $c$ onclude that $v$ iolencepromoting I slamist ex tremism ex ists in $\mathrm{S}$ weden and constitutes a po tential threat. $T$ hey $c$ laim $t$ o hav $e$ identified $\mathrm{j}$ ust $\mathrm{u}$ nder $200 \mathrm{i}$ ndividuals, mostly $\mathrm{m}$ en, domiciled i n S weden who hav e participated in or supported $v$ iolence-promoting I slamist ex tremism i $\mathrm{n}$ 2009 or I ater. W ithin $t$ his I arger group they hav $e$ isolated a $\mathrm{m}$ uch s maller group o fi ndividuals, whi ch they contend have the intent and capability to carry out a terrorist action, in most cases abroad. Subsequently, the rep ort e mphasizes that these pheno mena are a $t$ this time limited and s hould mainly be addres sed with more $f$ ocus on prev entive $m$ easures $t$ o $s$ top $t$ hem becoming a major problem for Swedish society. While the report hi ghlights ef forts to f acilitate s o c alled de radicalisation, such as ac tivities to hel $p$ those l eaving extremist $c$ ircles ${ }^{1}, t$ hey regard $t$ his $s$ trategy as a complement to the main s trategy of prev ention. The authors argue that de-radicalisation may risk having the opposite effect by instead driving forward radicalisation and that prevention instead of $t$ rying $t o$ de-radi calize active individuals is more resource-effective (p. 93).

Sweden has drawn up a na tional s trategy to address the $t$ hreat $f$ rom $t$ errorism (Government Communication 20 07/08: 64) and I ike the Uni ted Kingdom, the Netherlands, and neighbouring Denmark, Sweden in 2011 has a lso adop ted a na tional strategy to $c$ ounter $t$ he pheno menon o fex tremismo $r$ radicalisation ( Handlingsplan för att värna demokratin mot våldsbejakande extremism. Regeringens skrivelse

\footnotetext{
${ }^{1}$ The measure is comparable to the British "Channel" initiative which works at the local level with s mall numbers of "at risk" young people identified through multi-agency partnerships, which utilises a de-radicalisation approach (Thomas 2010: 450). In S weden it is not the S ecurity S ervice that c arries out de radicalisation initiatives, rather the Nat ional Board for Youth Affairs has bee $n$ commissioned $t$ o hel $p$ y oung pe ople I eave gr oups that pr omote po litical violence. In Sweden this de-radicalistion approach has only been implemented in conjunction with rightwing extremist youth.
}

2011/12:44;). The nat ional s trategy e mphasizes prevention $\mathrm{m}$ easures $\mathrm{t}$ hat abov $\mathrm{e}$ al $\mathrm{I}$ are $\mathrm{i}$ ntended to strengthen de mocratic a ttitudes a mong marginalized groups perceived as posing a t hreat, above all young people in depressed neighbourhoods. The greater part of the concrete measures listed in the report has been consigned to the B ureau of Youth Affairs to di stribute various project funds, together with the Council of Faith Societies $\mathrm{t}$ o di stribute dem ocracy prom oting educational projects to de facto Muslim congregations. In reg ard to the $\mathrm{m}$ easures $\mathrm{d}$ irected $\mathrm{t}$ owards the Swedish Muslim population, the re port describes what is perc eived as the pro blem by rel ying on what has become a prev ailing di scourse of radi calization an $d$ theories of radicalization processes focusing issues of lack of i ntegration, paral lel c ommunities, and an tiliberal a ttitudes am ong $\mathrm{M}$ uslim $\mathrm{m}$ inorities unders tood as prov iding a "br eeding groun d" $\mathrm{f}$ or radi calization (Bigo and Tsoukala 2008; Sedgwick 2010).

In the nat ional s trategy $t$ o c ounter $v$ iolencepromoting extremism the role of the Swedish Security Service is awarded one s hort paragraph, e mphasizing the $\mathrm{Na}$ tional Strategy $\mathrm{t}$ o Coun ter Terrori sm (s kr. 2007/08:64). In this s trategy progra mme the S wedish Security Service bears the responsibility to:

- $\quad$ Prevent recruitment into terrorism

- $\quad$ Avert threats from existing players

- $\mathrm{P}$ rotect from terrorism

This is mo re or le ss id entical to the p rogramme declaration o $\mathrm{ft}$ he Coun ter-Terrorism Coo peration Council, which the Service took the initiative to create in 2005. The Cou ncil is a c ollaboration of $14 \mathrm{~S}$ wedish government ag encies ${ }^{2} t$ oaddres $s t$ he $t$ hreat o $f$ terrorism. The S ecurity Service act $s$ as the Cou ncil's convenor and the Counc il's ai ms are to i mprove the participating agenc ies' collective ab ility to "ha ndle the consequences of a terrorist attack (p. 77), in addition to the three aims listed above ${ }^{3}$.

The first aim stressed in the report appears to form the $s$ trategic backbone of the State's counterterrorism

\footnotetext{
${ }^{2}$ The ag encies i nclude the Economic $\mathrm{Cr}$ ime A uthority, the $\mathrm{Na}$ tional $\mathrm{D}$ efence Radio Establishment, the Armed Forces, the Prison and Probation Service, the Coast Guard, the Migration Board, the C ivil Contingency Agency, the Nat ional Police Board, the Radiation Safety Authority, the Security Service, the Defence Research A gency, the $T$ ransport A gency, the Cus toms and $P$ rosecution Authority; none of these agencies are involved in so-called integration policies. ${ }^{3}$ These ar e mor e or less the $s$ ame $c$ omponents $h$ ighlighted in the $U \mathrm{~K}$ 's CONTEST antiterror programme: "Pursue, Protect, Prepare and Prevent".
} 
programme-de facto $f$ ormulated by the $S$ wedish Security Service.

\section{THE STUDY'S METHODOLOGY}

In order to ac quire an unders tanding as to how Muslim c ommunities perc eive the Swedish S ecurity Service's counterterror prevention strategy the study is built upon $\mathrm{m}$ ultiple em pirical sources. I mad Rasan, a doctoral $s$ tudent at $t$ he De partment of Sociology, University o f Lun $d, c$ onducted $i$ nterviews wi th representatives from $f$ our $M$ uslim umbrella organisations (f ive i nterviews; al I i n S tockholm) an d interviews with members from five different Muslim faith communities, i.e. Mosques in Gothenburg. The au thor conducted interviews with three members from Muslim faith $c$ ommunities in $G$ othenburg. $T$ he thirteen interviews i ncluded i nterviews with twelve $m$ en between the age of twenty-one and thirty-five and one woman in her $f$ ifties. The res pondents were as ked if and how t he S ecurity S ervice had approac hed them; how they had interpreted the 'dialogue' sought by the Service; and lastly, they were as ked to more generally reflect on th e Se rvice's a ctions to wards Muslims. As the $s$ tudy was perc eived $s$ ensitive $t$ he res pondents were as sured anony mity and s ubsequently they, and their organisations or Mosques, are not identified in the text. The interviews were recorded when permitted and transcribed or careful no tes were $t$ aken during the interview, which were later transcribed.

Most of the res pondents in our s tudy ref erred to specific actions taken aga inst Muslims in Go thenburg, which they perceived were i nitiated and conducted by the Security Service. Subsequently, the study includes germane $\mathrm{n}$ ewspaper ar ticles, w hich wer e supplemented by rel evant w ebsites and b logs, which provided statements by official spokesmen for some of the Muslim communities that our res pondents wer $e$ members of. As none of our res pondents were di rectly involved $\mathrm{i} n$ these actions $\mathrm{t}$ hat gar nered ex tensive media attention, these s ources prov ide the bac kdrop from wh ich our res pondents $c$ onstructed their narratives. Las tly, we hav e t aken i nto ac count t he report Violence-promoting Islamist extremism in Sweden (2010), which is the only official document that describes and explains the Security Service's strategy to prev ent radi calisation proc esses am ong Muslim young people.

\section{NEW GOVERNANCE SPACES OPENED BY THE SWEDISH SECURITY SERVICE}

The S wedish S tate's c ounterterrorism progra mme stresses the importance of prevention and the idea: is to make it more difficult for people who are al ready $v$ iolence-promoting to a tract new supporters, and to make fewer people receptive to and a ttracted by $\mathrm{v}$ iolencepromoting i deologies (Violence-promoting Islamist extremism in Sweden, 2010: 78).

To $\mathrm{m}$ eet $\mathrm{t}$ his aim the $\mathrm{S}$ ecurity $\mathrm{S}$ ervice has since 2003 conducted what they call ou treach activities. The objective of the outreach activities is to establish direct contacts with actors strategically important on the local level, s uch as community pol ice, $c$ ity d istrict c ouncils and civil society as sociations. In particular the Service seeks $t$ o es tablish $c$ ontact wi th and $c$ reate goo $d$ relationships wi th Sweden's prac ticing $M$ uslims. The outreach a ctivities of the Se curity Se rvice a re a $n$ attempt to $c$ reate ne $w$ s paces of gov ernance, wher $e$ Muslim c ommunities (and individuals) are ' invited' to participate in the S tate's counterterrorism progra mme. These "i nvited s paces" (Cornwa II 2004 ) ref lect wha t Raco (2003: 7 8) des cribes as the State's "i ncreased concern wi th de fining and $s$ haping ' appropriate' individual and c ommunity c onduct, regul ation an d control". According to Rose (1999), communities, and I would argu e i $n$ Sweden es pecially Muslim communities, hav e bec ome $z$ ones $t$ o be probed, mapped, c lassified, doc umented and ac counted for. I argue that the Security Service's outreach activities are the means by wh ich Muslim c ommunities ar e investigated and mapped through intelligence gathering and by whi ch the S ervice in the I ong-term s trives to shape the values and conduct of Swedish Muslims in general.

The initial ou treach ac tivities were $\mathrm{c}$ onducted on a small scale, first making contact wi th Muslim umbrella organisations and national orga nisations. According to the Security Service since then regular meetings have taken place with both national org anisations and local congregations i $\mathrm{n}$ Stockholm, Go thenburg, $\mathrm{M}$ almö, Umeå, Uppsala and Örebro to achieve a di alogue with Muslim c ommunities. The s ervice ac knowledges that cooperation es tablished wi th Muslim c ommunities is fundamental for their efforts.

Through a long-term ef fort to $b$ uild t rust and rel ationships wi th repres entatives of Muslim organisations, the Security Service hopes $t$ o c reate a $c$ limate $w$ here radicalisation and $v \quad$ iolence-promoting extremism $\mathrm{c}$ an be pr evented $\mathrm{t}$ hrough cooperation ( Violence-promoting Islamist extremism in Sweden, 2010: 78). 
What we found $\mathrm{i}$ nours tudy $\mathrm{i} s \mathrm{t}$ hat $\mathrm{t}$ he representatives of $v$ arious $M$ uslim $c$ ongregations i $n$ Gothenburg a nd Stockholm we i nterviewed den ied formal contact with the Swedish Security Service, bu $t$ they did indicate $\mathrm{t}$ hat $\mathrm{m}$ ost I ikely other $\mathrm{M}$ uslim organisations than their own do have different forms of cooperation with the Security Service. A few conceded that the Security Service had approached them at their mosque an $\mathrm{d}$ at tempted $\mathrm{t}$ o qu estion $\mathrm{t}$ hem, but they emphasize that $t$ hey are rel uctant to en gage $i \mathrm{n}$ conversations.

They hav e tried t o c ontact us and hav e come here (to the mosque), just like other police or ot her s tate i nstitutions. Some police o fficers c ome here and rec ord Friday sermons and prayer. However, we did no tc ooperate wi th the Security Service, even if they come here and try to discuss with us.

The report does not offer the reader a pi cture as to how these so-called ou treach meetings are c onducted nor how Muslim organisations have responded to these initiatives. We are only informed that their contacts with Muslim communities are good, wh ich is not, how ever, unequivocally ref lected i $\mathrm{n}$ our $\mathrm{s}$ tudy. I $\mathrm{n} \mathrm{c}$ ontrast ou $\mathrm{r}$ study indicates that the outreach activities have been imposed against a background of widespread mistrust. One respondent said that the Security Service of ficers were "very clever when I istening to us, f or example, they asked us if we have any problems. They tended to answer us and listen to our criticisms". Another clue as to how $t$ hese ou treach meetings are $c$ onducted i s revealed in an i nterview wi th a y oung $m$ an that had been c alled to a "d ialogue" i $n$ ear ly 2009 wi th two Security Service officers.

They as ked $m$ e what we do when we meet, what we talk about, what I do in my leisure time, what I think a bout jihad and whether I would consider whether I would call them if one of my students planned to travel to Iraq.... The Se curity Se rvice thinks that $w$ e a re a ll $p$ otential t errorists and $s$ uicide bo mbers $\mathrm{j}$ ust bec ause we practice our religion.

We found that the out reach ac tivities des igned to initiate a di alogue with Muslim communities are for the most part experienced rather as occasions where many have felt that they have been interrogated.
The repor $\mathrm{t} \mathrm{s}$ tates $\mathrm{t}$ hat $\mathrm{t}$ he ou treach ac tivities gi ve the $S$ ecurity $S$ ervice $t$ he opportunity to exchange information and $c$ ontribute to a nswering ques tions thereby av oiding $m$ isunderstandings. Ho wever, given that $t$ he $S$ wedish Security Service $i s$ the I east transparent of all of Sweden's gov ernmental a gencies with respect to the principle of secrecy applying to their on-going and pas $\mathrm{t} i$ nvestigations, it $\mathrm{i} s$ difficult to envision how and to wha tex tent $t$ he Service $c$ an reciprocally ex change $k$ nowledge or $t$ he degree to which they $\mathrm{c}$ an ans wer $\mathrm{c}$ oncrete ques tions. I $\mathrm{n}$ o ther words, the quality o $f$ the di alogue ac hieved $i s$ debatable. A res pondent $s$ tated that $t$ he $s$ o-called dialogues were not in fact di alogues. "I $t$ is rat her two parts who $\mathrm{n}$ eed to talk an $\mathrm{d}$ c ooperate arou nd c ertain issues". However, how trust can be realized given this institutional situation is not discussed in the report.

The onl y org anisational repres entatives that ad mit that t hey hav e regu lar $c$ ontacts $w$ ith the Security Service are those from umbrella organisations, which in itself is no $t$ controversial as these contacts are $t o b e$ expected given Sweden's corporate s tructure and that these organisations hav e rec eived gov ernmental funding. I $\mathrm{nt}$ hese cases of ficers from $\mathrm{t}$ he $\mathrm{S}$ ecurity Service book a time and come directly to their offices. According to most of our res pondents, the res ulting conversations are more or less directed to surveillance gathering.

They onl $y$ wan $t \mathrm{i}$ nformation $\mathrm{f}$ rom us ... what do we k now. Is there someone that we think is a potential extremist and so on. ... I think that their outreach programme is good i $f$ they wan $t t$ o bri dge $t$ he $g$ ap between the Security Service and Muslim communities, but i $f$ they onl y wa nt to retrieve information and perceive me as a link to extremists this programme is going down the wrong path.

On the other hand, one of our respondents (from a national $u$ mbrella organisation) gav $e$ us ano ther somewhat divergent picture as to how these meetings transpire.

The dialogue that takes place between the Security Service and Muslim organisations focus on ev eryday prob lems t hat $t$ hese organisations $f$ ace a nd $t$ he Security Service has $t$ ried $t \quad o$ help $M$ uslim organisations ov ercome these probl ems. In fa ct, th e Se curity Service has helped 
Muslim organisations with different issues, among others, $t$ enant $c$ ases, $t$ o i nvite guests $f$ rom ot her $c$ ountries, bui Iding permits, an d s o on. In ot her c ases, the Security Service has at tempted to s peak with the i mmigration of fice i $\mathrm{n}$ order to follow-up M uslim as ylum s eekers to hel $p$ them. Muslim organ isations think that in these cases the dialogue is excellent.

However, this res pondent was s ceptical as to whether the Security $S$ ervice $w$ as $t$ he a ppropriate governmental agency to solve these integration issues.

Why not the D epartment of I ntegration or the National Youth Board? It is very good that someone from the $S$ tate takes an interest i $n$ our prob lems, bu twhy $t$ he Security Service? I t i s v ery s trange that the Security $S$ ervice $d$ eals wi th $t$ hese kinds of i ssues. $T$ he qu estion re mains: what would the Security Service like to get back from us? Do t hey want information from us? ... Moreover, the term "prev ent activities" i s v ery probl ematical b ecause these ac tivities regard $M$ uslims as a problem and threat to society. That is why the gov ernment has commissioned the Security S ervice to start a dialogue with Muslims.

While $t$ he respondent abov $e$ admits $t$ hat the meetings $w$ ith $t$ he $S$ ecurity Service hav e res ulted in some bene fits for Muslim communities, he is more or less critical to the fact that it is the Security Service that is opening up new spaces of governance, whereby the state is seeking to engage with Muslim communities to prevent proc esses of rad icalization. In s hort, he i s critical to the fact that it is the Security Service that has extended the 'invitation' $t$ o $t$ hese i nvited s paces of governance and not $m$ ore appropri ate gov ernmental agencies with integration agendas. So despite what he sees as some benefits that have been attained through their meetings with the Security Service, he ap pears to be c onvinced that the 'hidden a genda' is, i n rea lity, intelligence gathering. Another respondent claimed that there i s s omething i nherently wrong "t hat the government uses $t$ he $S$ ecurity $S$ ervice $t o$ initiate a dialogue with Muslims".

The res pondents ex press a s imilar res ervation to the Service's $t$ argeting of a II M uslims wi th those Lindekilde (2012a an d 2012b) found in Den mark an d
Thomas (2010: 4 48) found in the U K. The S wedish Security $S$ ervice ap pears $t$ o hav $e$ made $t$ he $s$ ame mistake as $t$ he $B$ ritish $P$ reventing Violent $E$ xtremism programme "approaching an ent ire faith community as a whole, whi le forcing par ticular pol itical and doc trinal issues that have only limited meaning to most Muslims going abou $t \mathrm{t}$ heir ordi nary, day-t o-day I ives". The Service's outreach ac tivities $s$ ubsequently $t$ end to engage $S$ wedish $M$ uslims as an ' at ri sk's et of communities.

It $w$ ould a ppear that Muslim repres entatives perceive the outreach progra mme as $m$ ore or I ess a 'one-way d ialogue, $\mathrm{w}$ here the s ole o bjective of the contacts is to gather intelligence and not to bridge the gap be tween t he Security Service a nd Muslim communities.

I a m very di sappointed wi th the Security Service bec ause they $\mathrm{pl}$ ace al $\mathrm{l}$ o $\mathrm{ft}$ heir resources in controlling Muslim extremists and forget $t$ hat there are $o$ ther forms of extremism that are coming from right wing groups and I eft au tonomous groups. These groups pos e a danger $f$ or democracy in Sweden and when I see that democracy in Sweden is threatened I am disappointed. ... I would appreciate it if the Security $S$ ervice t ook their responsibility and deal $\mathrm{t} w$ ith ex tremism ac ross $\mathrm{t}$ he board, and not only Muslim extremists. We feel that we are c onstantly u nder threat, particularly when we rec eive threatening mail a to ur office. Ex tremists have searched after my home address and sent me th reatening mail. I would appreciate it if the Security Service took these threats seriously. ... As a M uslim I w ant to fe el safe from ra cists a nd it is the Security Service's duty to pro tect me from these threats, just as they have to pro tect nonMuslims from fundamentalist groups.

Research has consistently found that ethnic minority groups feel that as victims of crime, they are not taken seriously and $t$ he res ponse by the pol ice is often regarded as inadequate (e.g. Sharp and Atherton 2007;

\footnotetext{
${ }^{4}$ Even the u niformed police in Sweden have complained about the 'one-way' nature of the Security Service's dialogue. The informants from the 'open police' authority in a study of inter-agency par tnership in the a nti-terror programme claimed that the Security $S$ ervice de mands i nformation, but does no $t$ reciprocate with feedback (Ranstorp and Dos Santos 2009: 19).
} 
Desmoyers-Davis 2003; Spencer and Ho ugh 2000;). It would app ear $\mathrm{t}$ hat the o utput o $\mathrm{ft}$ he ou treach programme falls we II s hort of $i$ ts i ntentions. "I $n$ the wake of the terrorist attacks o $n 11$ S eptember 2001 and the pre judice that many Muslims then faced, and still face, the S ecurity Service a ims to s how that it is there to serve everyone, as an obv ious cooperation partner" ( Violence-promoting Islamist extremism in Sweden, 2010: 78; my emphasis;). If it is the Swedish Security Service's du ty to serve and protect everyone this res pondent is not $c$ onvinced that the $S$ ervice is fulfilling its duty.

In addi tion t $o$ meetings $w$ ith repr esentatives of Muslim interests in order to prom ote cooperation wi th Muslim co mmunities i $n$ Sweden, a ccording to the Security Service they have met as well with individual practising $M$ uslims, par ticularly y oung $m$ en, much i $n$ line with the Danish Security and Intelligence Service's "preventive talks" ( $\mathrm{L}$ indekilde 2 012). Thi $\mathrm{s}$ was no $\mathrm{t}$ discussed in the report and we only have the accounts of the young men who have been called to their offices. However, these 'meetings' would appear to be solely to secure i nformation. Wh at $h$ as been re ported o $n$ Websites and $b$ logs, together $w$ ith $i$ nterview confirmation i no ur s tudy, is t hat the y oung men contacted feel that they have no op tion but to come to these 'meetings'. "If we don' $t$ agree to meet with them they will think that we are c oncealing something". This was $t$ he $s$ ame $i$ nterpretation $t$ hat on of ou $r$ respondents provided regarding the Security Service's "invitations" to meet for a di scussion. "If y ou refuse to cooperate they will think that y ou have something to hide." Another res pondent s aid that he, as a ' second generation' $S$ wedish $\mathrm{M}$ uslim, can criticize them and argue with them "but the first generation men are very careful and they $f$ eel uns afe when talking $w$ ith the Security Service. The old men feel that they are forced to talk to the Security Service". In o ther words, these invitations are perceived as a s ubtle form of c oercion reminding us that in the "invited spaces" of governance it is $t$ he $S$ tate, in $t$ his case, $t$ he $S$ wedish $S$ ecurity Service, that de fines 'the rul es of the ga me' and $s$ ets the parameters of participation (cf. Taylor 2007: 302).

By attempting to mobilize all Muslims, the failure of Muslim individuals or organisations to comply with this mobilization $m$ akes $t$ hem $s$ uspect in the ey es of the counterterrorist system (cf. Akram and Joh nson 2002; Kundani 2009 : 15 regard ing $\cup \mathrm{K}$ ). But as Kundani points ou $t, M$ uslims $m$ ay $v$ ery wel I av oid a $S$ ecurity Service's i nvitation to $c$ ooperate $f$ or a num ber of reasons that have nothing to do with support for violent terrorist $t$ actics. I wou ld arg ue that the rel uctance of Muslim c ommunities $t$ o en gage wi th the $S$ wedish Security Se rvice is a form of community re sistance to cooptation and colonialisation in order to maintain their credibility and legitimacy with their congregations. Even if many of the informants in our study tended to regard the Service's 'invitations' as more or less mandatory to comply with, they are not forced to ent er these ne w governance $s$ paces wi th $f$ ull c ooperation. Morison (2000: 131) argues that there are a Iways s ome organisations and $\mathrm{c}$ ommunities that rem ain "incompletely dom esticated". Many of the representatives of $t$ he Muslim c ommunities w e interviewed bear witness to tactics of non-compliance with the $S$ wedish $S$ ecurity $S$ ervice $t$ hat can be interpreted as a form of res istance to cooptation and colonialisation. Th ey ei ther ref use t o $t$ alk $t o$ of ficials from the $S$ ervice or ref use to prov ide $t$ hem wi th information. For ex ample, one y oung $m$ an who wa $s$ interviewed claimed that Security Service showed him pictures of other politically or religiously active Muslims and as ked $\mathrm{h}$ im if he could identify them. He reported that he did recognize all of the men but denied that he knew them. In s hort, he complied to meet wi th the Security Service, but he ac tively withheld information. Another s trategy ex pressed by a repres entative from an umbrella organisation was to meet with the Security Service c ollectively. "If t he S ecurity S ervice w ants to meet wi th M uslim organisations, then we are $s$ even organisations in one appointment". In this way they tried to infuse the 'dialogues' with the Security Service with a de gree of transparency for the congregations they represent. They were extremely reluctant to meet with officers from the Security Service alone.

Sweden's policy of multiculturalism has traditionally engaged with the c ountry's i mmigrant and ref ugee population in terms of e thnic b ackground, that is, the state on local and national levels has encouraged and supported ethnic minority organisations and teaching in mother tongue I anguages. The $\mathrm{m}$ ulticultural model seeks to support cultural difference and awards ethnic minorities s pecified c ultural ri ghts. I mmigrant organisations were more or less organi sations that encouraged and protected the cultural identity of ethnic groups in Swedish society (Dahlström 2007). However, integration pol icy has more and more gone $b$ eyond ethnicity to focus religiosity. Since the latter 1990s the Swedish State has i ncreasinglys ought multiethnic partnerships wi th so called faith communities. Dinham and Lowndes (2008: 824) argu e that wi thin pu blic discourse in Britain onl y M uslims hav e faith, "and a 
potentially dang erous $f$ aith a $t \mathrm{t}$ hat". Th is c urrent i $n$ public di scourse appears in Sweden as well, wher e faith is di scursively c onstructed as a proper ty of the "Other". Partnerships $h$ ave be en s ought wi th the various Muslim communities in the country, which are perceived in general as $v$ ulnerable to $p$ ersuasion to support terrorism. In our study this targeting of Muslim faith communities appears to have led to a widespread sense of victimization (see Lindekilde 2012a and 2012b for similar conclusions from his Danish study;).

When the suicide bomb attack was carried out l ast y ear on Dro ttninggatan, it s eems that t he $S$ ecurity Service's procedures were $c$ ompletely u nacceptable. A fter the assault $t$ heir terrorist ex pert Magnus Ranstorp referred in the media to Muslims as $\mathrm{s}$ uspected $\mathrm{t} o$ lie beh ind $\mathrm{t}$ he at tack. I was very angry because they pointed their finger at all Muslims, stereotyping Muslims as ev erything wrong in s ociety. We as Muslims are al so exposed to threats just like ev eryone el se. We $d$ id not rec eive a SMS to vacate the street because we are Muslims. It wa $s$ noto nly a $t$ hreat $t o$ Swedes, it was al so a t hreat to Muslims and dem ocracy. When the terrorist at tack took pl ace i n Norway Magnus Rans torp was quick to once again point his finger at Muslims a s su spects b ehind $t$ his attack. (respondent from an $u$ mbrella organisation)

The Swedish Security Service's attempt to mobilize all Muslims is a form of religious profiling that, in effect, constructs Muslims i nto as uspect c ommunity, a criminal threatening Other. In Lindekilde's (2012b: 17) study, $t$ he $m$ ajority o $\mathrm{fM}$ uslims $\mathrm{t}$ hey $\mathrm{i}$ nterviewed perceived the Danish radicalization policies, which they felt $t$ argeted al I practicing $M$ uslims in ge neral, as a misrecognition of their value as citizens. In s hort, the Danish Muslims in their study felt that the Danish action plan s tigmatized all $\mathrm{M}$ uslims as potential terrorists. Their conclusions dovetail with those we reached in our Swedish study. A hmed Al-Mofty, who is the President of the I slamic Information $A$ ssociation and $t$ he foundation behind $t$ he new $m$ osque in Go thenburg, claims that he does $n$ ot wa nt to have anything to $d o$ with the Security Service.

They are s o unpro fessional. The ir actions do not further or $f$ it in wi th a de mocratic society. $P$ eople $f$ eel harassed, $t$ hey accuse peopl e w ithout s upporting evidence and say that they have facts that they don't. We M uslims feel accused all the time as i f w e were c riminals. (http:/www.gp.se/nyheter/goteborg/1.7255 39-garna-polisen-inte-sapo)

Waddington (1999: 41) argues that the "police patrol the bound aries of citizenship: the c itizenship of those who are ' respectable' i s s ecured, w hile those wh o attack the state ex clude themselves from citizenship". Between these pol ar ex tremes we $f$ ind a grey $z$ one wherein those $w$ hose c laim to c itizenship is insecure and needs repea tedly to be $n$ egotiated. Following this line of thought contact with Swedish Security Service officers inherently challenges c laims to c itizenship, of being valued members in the broader society. Contacts with the Sw edish Security Service officers, c an e ither be interpreted as communicating that one is a $v$ alued member of the community and that on e's group, sic Muslims, are $v$ alued $\mathrm{i} n$ Swedish s ociety or not. Encounters with $t$ he $S$ ecurity $S$ ervice can at best confirm the individual's s ocial s tanding and $h$ is or her group's social standing, but there are many possibilities that $t$ he enc ounter wi ll und ermine the $s$ tatus of the contacted $\mathrm{i}$ ndividual res ulting $\mathrm{i} \mathrm{n}$ res entment a $\mathrm{s}$ witnessed in the narrative above.

While the report highlights prevention, emphasising integration $s$ trategies, a s oft $s$ ecurity a genda, this agenda has inherent c ontradictions wi th the counterterrorism progr amme's ai ms $t \mathrm{o}$ ov ert $t$ hreats $f$ rom existing players and to protect from terrorism, classical hard $s$ ecurity agend as bas ed on $s$ urveillance and control. The $c$ ritics of the $B$ ritish Prevent progra mme point out $t$ hat Muslim communities with who $m$ the government has sought to enga ge were $s$ uspicious of an engage ment plan that was seen as ent renched in the $s$ urveillance and police $c$ ontrol o $f$ Muslim populations m ore gen erally (Kundnani 2009; Thomas 2010). The two logics of engagement would appear to be at odds. On $t$ he one hand the $S$ wedish $S$ ecurity Service, like its counterpart in Britain, seeks to engage with Muslim communities as a res ource in the national and local s tate's integration ef forts, on the other han d the Security Service i s opera tionally dri ven by a surveillance and risk logic. While the Security Service invited $\mathrm{M}$ uslim $\mathrm{s}$ takeholders to par ticipate in a workshop that prov ided $v$ aluable insight and $i$ nput to their repor $t$ Violence-promoting Islamist extremism in Sweden (2010:78), this i s a $n$ unus ual mode of information gathering. Fur thermore, we do no $t$ know to what extent that the concluding reflections in the report 
actually $i$ mpact $t$ he opera tionalisation o $f t$ he Counterterrorism $P$ rogramme. Th e logic of perc eiving Muslim groups as $\mathrm{c}$ ivil s ociety repres entatives an $\mathrm{d}$ stakeholders is by al I ac counts new $f$ or the $S$ wedish Security Service and we have little evidence that this logic is not s uperseded by its stronger and traditional risk logic of $s$ urveillance and $c$ ontrol, leadin $g$ t o a $n$ engagement wi th $\mathrm{M}$ uslims as $\mathrm{s}$ uspects rat her $\mathrm{t}$ han citizens (cf. Birt 2009 regarding the UK).

The rol e of i nitiator $f$ or a radi calization prev ention strategy $h$ inging on i ntegration and a nti-discrimination measures, whi ch $w$ as pus hed upon the Security Service by politicians, is in itself an a nomaly given its traditional $r$ ole of $p r$ oviding intelligence and $s$ ecurity. Not unpre dictably, the re presentatives of the Muslim communities that we interviewed were s ceptical to the appropriateness o $\mathrm{ft}$ he Security $S$ ervice's $\mathrm{s}$ oft approach: "W hy not the Dep artment of Integration or the Na tional Y outh Board?". Ra ther they thought that the approac $h$ was a rus e f or $i$ ts do minant I ogic of surveillance and pol ice c ontrol: "Do $t$ hey want information from us?".

\section{RECIPROCAL TRUST AND PROCEDURAL JUSTICE}

Researchers and prac titioners al ike hav e emphasized $t$ he $i$ mportance o fpol ice-community relations based on reciprocal trust for police-community cooperation. Th is ho lds true not onl y for pol icing i $n$ general, but also for counterterrorism or 'high-policing' in particular. As Oliver (2006: 192) points out,

citizens' willingness to provide in formation on terrorism to the police can in no way be taken $f$ or gran ted, as $s$ uch $c$ ontact between $t$ he $p$ olice an $d t$ he $c$ ommunity demands a significant degree of reciprocal trust.

When $t$ he pub lic perc eives pol ice ac tions as legitimate and $f$ ostering proc edural justice, i.e. due process of law and fairness to all, there is an increase in genera I s atisfaction a nd c ooperation (Hough and Roberts 2004; Tyler 2006 ; S kogan 2006 ; S kogan and Frydl 20 04; Bradford et al. 2 009; Ja ckson and Sunshine 2007; Jackson and Bradford 2009; Sindall et al. 2012 ;). The e ffectiveness of $t$ he $s$ tate's proac tive counterterrorism me asures-intelligence gathering, surveillance and preventive progra mmes-rests upo $n$ the degree $t$ o whi ch rel evant pop ulations hav $e$ developed sufficient trust and confidence in the police, both state and local (cf. Lyons 1999).
Then, wha $t$ are the policing $s$ trategies, $w$ hich enhance, al ternative di minish, publ ic c ooperation? Tyler (2006) distinguishes between two mechanisms by which policing can reduce levels of social disorder: the instrumental and the normative. In the former model of social control individuals calculate the expected costs and $b$ enefits from c ompliance $w$ ith th el awo $r$ cooperation with the police. They comply or cooperate only when $t$ he benefits out weigh $t$ he costs. Th $e$ alternative $\mathrm{m}$ odel e mphasizes se If-regulatory, normative motivations for compliance and cooperation. People comply a nd cooperate when they b elieve that authorities are I egitimate and en titled to be obey ed. The research of Tyler among others has established a robust link between cooperation, institutional legitimacy and the concept of procedural justice, i.e. the fairness of police procedures.

The $f$ airness of pol ice proc edures depends, for example, on $t$ he $m$ anner in which street stops are conducted, whether the po lice are neutral and transparent in their a pplication of fle gal $r$ ules, $w$ hether they ex plain their ac tions and s eek input from community members before making decisions, and whe ther they treat peop le with $d$ ignity and $r$ espect. $J$ udgements about procedural justice have been found to i nfluence t he perc eived I egitimacy of law enf orcement and $t$ hus $t$ o a ffect willingness t o c omply a nd $\mathrm{t} \mathrm{o} \mathrm{c}$ ooperate (Tyler, Schulhofer and Huq 2010: 367).

The $s$ elf-regulatory normative $m$ odel has be en widely s upported in s tudies of po licing ord inary c rime. Whether $\mathrm{t}$ his $\mathrm{m}$ odel a pplies as wel It $\mathrm{o}$ anti-terror policing is the question posed by Tyler, Schulhofer and Huq (2010). They tested the relative significance of the normative model in the context of antiterrorism policing within d omestic U S. Muslim co mmunities co ntrasting deterrence an $d$ l egitimacy as ri val ex planations $f$ or cooperation. These res earchers $f$ ound a $s$ trong correlation be tween perc eptions of proc edural j ustice and bot $h$ per ceived legi timacy and $w$ illingness $t o$ cooperate among Muslim American communities in the context o f ant iterrorism pol icing. Fur thermore $t$ hey found that religiosity, cultural di fferences, and po litical background hav e at b est weak c onnections wi th cooperation. Subsequently, they argue that procedural justice considerations must be infused in the design of antiterrorism pol icing s trategies $\mathrm{c}$ oncerning Muslim Americans in the U.S. 
The study finds that the procedural justice of the police when implementing antiterror policing po licies s hapes $t$ heir I egitimacy and al so i nfluences bot $\mathrm{h}$ gener al cooperation and willingness to contact and alert law en forcement to terror threats ( $p$. 386).

A res pondent in our s tudy de fined his rel ationship with the Security Service in the following words:

We $f$ eel o ffended when $t$ he $S$ ecurity Service sa ys that we wa nt to co operate with y ou and we want to i mprove our relations wi th $y$ ou and a $t \mathrm{t}$ he $\mathrm{s}$ ame time they take o ffensive ac tions against Muslims in a mosque in $\mathrm{G}$ othenburg and point their weapons against children there. There is systematic discrimination against Muslims when the Security Service deal s solely with Muslim extremism and not nonMuslim extremism.

A legitimacy-based model of policing suggests that the publ ic ev aluates pol ice, c ourts, and $t$ hel aw primarily in terms of how authority is exercised (Tyler 2006). In the following pages we will counter pose the empirical examples of $t$ he ac tions of $t$ he Swedish Security Service, in cooperation with the regional police authority, i n c onnection wi th the apprehe nsion and arrest of $s$ uspected Muslim t errorists i $n$ G othenburg with e lements i $n$ the $c$ oncept of pr ocedural justice. Procedural justice has two elements: the quality of the process used to make decisions, and the quality of the interpersonal t reatment peopl e rec eive when deal ing with aut horities. Spalek et al. $(2008)$ have found that the ' hard' an ti-terror pol icing appro aches us ed in the UK, including intensified $s$ top and $s$ earch, high prof ile raids leading to non-convictions, and the perception of an es calation $\mathrm{i} n$ aggres sive at tempts at rec ruiting informers, are "c reating barri ers t o good pol icecommunity rel ations and $s$ ubsequent $p$ artnership" ( $p$. 9). Thes e a pproaches hav e l ed to breaches in the quality of proc edural $\mathrm{j}$ ustice enc ountered by Muslim communities in the UK and, according to Spalek et al. (2008), has helped to create a sense of grievance and feelings that they are "s uspect communities". C an we find similar elements in the Swedish Security Service's 'hard' po licing approac hes, wh ich can be expected to likewise under mine the intentions of their s oft s ecurity prevention programme?

December 11, $2010 \mathrm{i} \mathrm{n} \mathrm{S}$ tockholm wi tnessed the only Muslim terrorist action, which has taken place in
Sweden; an aborted suicide bombing which caused the death of the Swedish Muslim bomber but did not result in further deaths or injuries among the people shopping in the $\mathrm{s}$ treet a $\mathrm{t}$ the $\mathrm{t}$ ime. The man $\mathrm{h}$ ad repor ted the motive for his action to be influenced by the artist Lars Vilks' draw ings of the Prophet M ohammad as a s o called traffic roundabout dog. Since the inception of the 2003:148 A ct on Cri minal Res ponsibility f or T errorist Offences, $40 \mathrm{i}$ ndividuals hav e bee $\mathrm{n} \mathrm{pl}$ aced under arrest, $f$ ew hav e been brough $t \mathrm{t} o$ trial and on ly $t$ wo have resulted in convictions (at the time of writing). In the following paragraphs I will briefly account for some of $t$ he more $s p$ ectacular ra ids a gainst su spected Muslim terrorists in West Gotalands Police District.

On Oc tober 30, $2010 \mathrm{in}$ the e arly m orning hours three families were brought in for ques tioning by the national s wat team, whi ch were he avily arm ed. The doors of $t$ heir ho mes were brok en down a nd the families held under gunpoint, including three children. Three men $w$ ere $s$ ubsequently de tained $f$ or $f$ urther questioning in regards to suspicion of preparation of a terrorist $b$ ombing a gainst th e ci ty's major sh opping mall. Th e $\mathrm{m}$ en $\mathrm{w}$ ere $\mathrm{s}$ hortly a fter rel eased from questioning a nd a fter ten days al I $c$ harges wer $\mathrm{e}$ dropped. It was later revealed that the warrant for their arrest was dec ided by the s pecial pros ecutor for terrorist offences, without $h \mathrm{im}$ having read the witness interrogations, whom he had nonetheless described as highly c redible. The wi tness, a t hirty-year-old wo man with a I imited c omprehension of Arabic, had heard a very tall $A$ frican $m$ an $s$ cream into a $m$ obile telephone about a bo mb in the mall. The single witness in a later interrogation retracted her statement, now claiming that the $m$ an was nei ther $t$ all nor $A$ frican. One of the suspects ad mitted to talking i $\mathrm{n}$ a $\mathrm{m}$ obile about hi $\mathrm{s}$ 'exploding headache', which was an expression used in a hi ghly $t$ elevised $c$ ommercial $f$ or a hea dache preparation hi ghlighting an et hnic $\mathrm{m}$ inority man describing the pai $\mathrm{n}$ i $\mathrm{n}$ hi s h ead. (Göteborgs-Posten, 2011.12.16, p. 17)

The men, with backgrounds in Syria, were a fforded an i nformal apology by the Di strict's pol ice c hief Ingemar $\mathrm{J}$ ohansson. Whi le $\mathrm{J}$ ohansson ex pressed hi s regrets ov er $t$ he $m$ istake, he was repor ted to hav $e$ explained to the men that as they came from countries and cultures where terrorism was common they could not be expected to be treated like an ordinary Swedish family from the count ryside (ht tp://www.aip.nu/default. aspx?page=3\&nyhet=41484). In c onjunction wi th this episode ei ght $\mathrm{m}$ en were de tained $\mathrm{i} \mathrm{n}$ a $\mathrm{m}$ osque $\mathrm{f}$ or 
questioning and $\mathrm{t}$ he $\mathrm{m}$ osque was $\mathrm{s}$ earched, whi ch contributed to further alienating the Muslim community.

Zana Muhammed, when he was active in Sweden's Young Muslims in the early 2000s, agreed to meet with Security Service officers. He thought that the meeting was a little exciting. They told him about their activities and which organisations were "dangerous". However:

I would n ever do t hat t oday. I hav e l ost hope a fter h ow the Security S ervice has treated M uslims in Got henburg. When they break i nto the homes of innocent families and point their automatic weapons at them in front of their wives and children. I don't trust them. What happened to those men last fall could just as well happen to me. (h ttp:/www.gp.se/nyheter/goteborg/ 1.725539_garna-polisen-inte-sapo)

Omar Mustafa, $t$ he $P$ resident of $t$ he I slamic Association, spoke in the same vein.

What ha ppened i n Go thenburg a nd Gårdsten's Mosque was a catastrophe. ... At th e s ame ti me that they i nitiate a dialogue $t$ hey $m$ ake $t$ hese $k$ inds o $f$ mistakes. They would have never entered a Christian church in this way. The biggest problem is that when they do something wrong they can't explain to us why. Many Muslim as sociations are tired o $\mathrm{ft}$ his. (http:/www.gp.se/nyheter/goteborg/1.7255 39-garna-polisen-inte-sapo)

September $11^{\text {th }} 2011$ four m en were arrested in a high-profile ra id for $p$ lanning a terrorist a ttack on the Gothenburg arts centre Röda Sten-ten years after the 9/11 a ttacks. T his wa s a ra id wh ich $\mathrm{g}$ arnered $\mathrm{g}$ lobal media at tention. Originally the men were rep orted in the $\mathrm{m}$ edia $\mathrm{t} \mathrm{o}$ hav $\mathrm{e} \mathrm{pl}$ anned a $\mathrm{t}$ errorist a ttack wi th automatic weapons and bombs. A few days later one of the men was released from custody, however, three of the men re mained held in custody for several months and $t$ heir de tainment was $s$ hrouded by an un usual degree of s ecrecy. Th e s pecial pros ecutor rel eased neither the charges nor the grounds for the charges to either the de tained s uspects' I awyers or $t$ he media. First a fter a $f$ ew week $s$ duri ng the arrai gnment procedures the charges were dropped from preparation of a terrorist attack to preparation of murder. The three men wer e now $c$ harged wi th $p$ lanning the murder of artist Lars Vilks $\mathrm{w}$ ith a $\mathrm{k}$ nife a nd were ret ained i $\mathrm{n}$ custody. $S$ everal $m$ onths later when $t$ he $m$ en were finally put on $t$ rial $t$ he $c$ harges were then drop ped against two of the men and one $m$ an was found guilty of carrying a c oncealed we apon-a pocket-knife-and fined. Obviously, this was again an e mbarrassing case for the Swedish Security Service an $d$ their ant i-terror actions.

These are a few of the more high profile antiterrorist actions by $t$ he $S$ wedish $S$ ecurity Service $i$ Gothenburg, whi ch argua bly di d no thav e proc edural justice $i \mathrm{n}$ the $f$ oreground. They a ppear to hav $e$ alienated the Muslim communities we s tudied and the events were rel ated in our res pondents' narra tives of what they felt were cases of unjust treatment. One or more of these actions were mentioned by all but three of the res pondents in our s tudy as ex amples of what they perceived as examples of unfair treatment by the Swedish Security Service. While their narratives did not necessarily prov ide ac curate ac counts, f or ex ample, the actions in real ity were $c$ arried out by the Regional Police Authority, they all attributed what they regarded as unfair policing procedure to the Security Service. So while the Swedish Security Service is cognisant of the need to gain the support of Muslim communities in their counterterrorism ef forts $t$ hrough improving policecommunity rel ations, we $\mathrm{c}$ an $\mathrm{w}$ itness an i ncreasing alienation among $\mathrm{S}$ wedish $\mathrm{M}$ uslims in regards to the police. I n G othenburg, Sweden's s econd I argest c ity with a large number of Muslim communities, a series of police and publ ic pros ecutor ac tions aga inst Muslims suspected of $t$ errorist ac tivities has out raged a significant prop ortion of the Muslim popu lation undermining the relations with the pol ice, in part icular the Swedish Security Service. Not only do actions such as these under mine the cooperation they seek in their outreach progra mme, res earch suggests that intrusive measures can potentially stimulate terrorist recruitment (Donohue 2008).

\section{CONCLUSIONS}

\section{Preconditions for Cooperation}

As Murphy, Hinds and Fleming (2008) point out that while the police have the power to regulate people by applying or threatening to apply sanctions, their ability to co ntrol cri me more effectively i s si gnificantly enhanced by i ncreasing publ ic c ooperation. I $n$ their study they found that:

a proc ess-oriented s trategy to p olicing which places proc edural justice a nd trust 
in the foreground of enc ounters wi th the public - serves to build and $m$ aintain the legitimacy of police, which then makes it easier for them to encourage community cooperation (p. 140).

Their c onclusions reg arding pol ice-community relations $m$ ore gen erally dov etail wi th the findings of Tyler, S chulhofer an d Huq (2010) who s pecifically studied how procedural justice impacts the effectivity of counterterrorism pol icing. I n s hort, $f$ air proc edures practiced $t$ owards communities communicate $t$ o t he group res pect and $v$ alue, $w$ hile $u$ nfair proc edures communicate di srespect and $m$ arginality. I $n$ our $c$ ase the ac tions of $S$ wedish Security Service-in conjunction wi th hi ghly $\mathrm{m}$ edialised de tainments an $\mathrm{d}$ arrests and in conjunction with the Service's ou treach programme which is seen as veiled attempts to procure information and $w$ hich i s perc eived to $v$ ictimize a II Muslim c ommunities as $\mathrm{s}$ uspects i $\mathrm{n}$ Sweden's counterterrorism progra mme-has no $\mathrm{t} p \mathrm{pl}$ aced procedural justice in the foreground. Procedural justice, during both pol icy $f$ ormulation in $S$ weden's counterterrorism programme and in the implementation of $i$ ts $m$ easures, $s$ hape the a ttitudes of $S$ wedish Muslims t owards $c$ ooperation or $n$ on-cooperation. I $f$ these $c$ ommunities do not perc eive that $t$ hey ar $e$ viewed as valued members of society, sic "respectable citizens" (Wad dington 19 99: 41), they c annot reasonably be ex pected to as sist the Security Service in their counterterrorism efforts.

Furthermore, the $S$ wedish $S$ ecurity $S$ ervice's outreach progra mme's focus on M uslim communities may ev en be c ounterproductive bec ause of the suspicions and $\mathrm{m}$ istrust $\mathrm{t}$ hat $\mathrm{t}$ his approach $\mathrm{t}$ ends $\mathrm{t} \mathrm{o}$ provoke am ong ordi nary Muslims. Our i nformants described $t$ he out reach activities, the "invitations $t o$ dialogue' i nitiated by the Security Service, as crudely veiled a ttempts to proc ure information and not as a $n$ attempt to es tablish a relation of trust and reciprocity. Comparable $t o$ the Dan ish ac tion $p$ lan agai nst radicalization, the Swedish Security Service's outreach programme can have the unintended consequence that young Muslims can "isolate from majority society and actively discredit au thorities (Li ndekilde 2012a: 2 6). Instead of c ounteracting radi calization proc esses, the programme, whi ch $\mathrm{t}$ argets prac ticing $\mathrm{M}$ uslims as per definition potential terrorists, $c$ an $v$ ery wel II ead to radicalization a mong y oung Muslims with experiences of misrecognition. Lindekilde (2012b) argues that when Muslims are $t$ argeted as a genera lized potential threat and Muslims $p$ erceive $p$ olicies as di scriminatory and stigmatising, ac tion pl ans agai nst rad icalization c an result in b oth s hort an d I ong ru n "bac kfire processes" that i $\mathrm{n} t$ urn I ead to an acceleration of radi calization processes among many "home grown terrorists".

\section{ACKNOWLEDGEMENT}

The work was supported by the Swedish Research Council f or Work ing $L$ ife a nd $S$ ocial Res earch (gran $t$ number 2009-0 011). The da ta c ollection was largely carried out by Iman Ras ad, Department of Sociology, Lund Uni versity, S weden. Th e aut hor wou Id I ike t o acknowledge the helpful comments of the reviewers.

\section{REFERENCES}

Akram, Susan M . and Kevin R. J ohnson (2002) "Race, C ivil Rights, and I mmigration Law A fter $S$ eptember 11, 20 01: $T$ he Targeting of A rabs and Muslims". New York University Annual Survey of American Law. 58: 295-355.

Bigo, D idier and A nastassia T soukala (2008) Terror, Insecurity and Liberty. New York: Routledge.

Birt, Yahya (2009) "Promoting Virulent Envy? Reconsidering the UK's Terrorist P revention S trategy". Royal United Services Institute Journal. 154(4): 52-58.

Bradford, B en, Jon athan Ja ckson and E lizabeth S tanko ( 2009) "Contact a nd $\mathrm{C}$ onfidence: $\mathrm{R}$ evisiting $\mathrm{t}$ he I mpact o f $\mathrm{P}$ ublic Encounters with the Police". Policing and Society. 19(1): 2046.

Cornwall, Andrea (2004) "New de mocratic s paces? The politics and dynamics of institutional participation". IDS Bulletin. 35(2): 1-10. http://dx.doi.org/10.1111/j.1759-5436.2004.tb00115.x

Dahlström, Carl (2007) "Modeller för invandrarpolitik". Pp. 26-43 in A Peterson and M.H jerm ( eds) Etnicitet: Perspektiv på samhället. Malmö: Gleerups.

Desmoyers-Davis, T revor (2003) Citizenship in Modern Britain, $2^{\text {nd }}$ edn. London: Cavendish.

Dinham, A dam and V ivien Low ndes (2008) "Religion, R esources, and Representation: Three $\mathrm{N}$ arratives of $\mathrm{F}$ aith $\mathrm{E}$ ngagement in B ritish U rban G overnance". Urban Affairs Review. 43(6): 817-845.

http://dx.doi.org/10.1177/1078087408314418

Donohue, La ura ( 2008) T he C ost of C ounterterrorism: p olitics, Politics, a nd Liberty. $C$ ambridge: $C$ ambridge $U$ niversity Press. http://dx.doi.org/10.1017/CBO9780511551192

Hasisi, B adi, Geoffrey P. Alpert and D an Flynn (2009) 'The Impacts of Policing Terrorism on Society: Lessons from Israel and the US'. Pp. 177-202 in D. Weisburd et al. (eds) To Protect and To Serve: Policing in an Age of Terrorism. Springer Science and Business Media.

Hough, Mike a nd J ulion R oberts (2004) Confidence in Justice: An International Review. London: Home Office.

Jackson, Jo nathan and B en B radford (2009) "Crime, P olicing a nd Social Order: On the Expressive Nature of Public Confidence in Policing". British Journal of Sociology. 60(3): 493-521. http://dx.doi.org/10.1111/j.1468-4446.2009.01253.x

Jackson, Jonathan and Jason Sunshine (2007) "Public Confidence in Policing: A Neo-Durkheimian Perspective". British Journal of Criminology. 47(2): 214-233. http://dx.doi.org/10.1093/bjc/azl031

Kundnani, A run ( 2009) Spooked! How Not to Prevent Violent Extremism. London: Institute of Race Relations. 
Lindekilde, Las se ( 2012a, $f$ orthcoming). "Neo-liberal Governing of 'Radicals': $D$ anish $R$ adicalization $P$ revention $P$ olicies an $d$ Potential I atrogenic Effects". International Journal of Conflict and Violence. 5(2).

Lindekilde, Lasse ( 2012b, f orthcoming) " A T ypology o f B ackfire Mechanisms: How Hard and Soft Forms of State Repression Can Have Perverse Effects in the Field of Counterterrorism". In L. Bosi, C. Demetriou and S. Malthaner (eds). A ProcessOriented Perspective on Radicalization and the Escalation of Political Conflict. Ashgate Publishing Ltd.

Lyons, W illiams ( 1999) "Partnership, i nformation and pu blic s afety: Community po licing in $\mathrm{t}$ imes o $\mathrm{ft}$ error". Policing: $A n$ International Journal of Police Strategies and Management. 25(3): 530-542. http://dx.doi.org/10.1108/13639510210437023

Morison, J ohn ( 2000) " The G overnment-Voluntary S ector Compacts: Governance, Governmentality and Civil Society". Journal of Law and Society. 27(1): 98-132. http://dx.doi.org/10.1111/1467-6478.00148

Murphy, Kristina, Lyn Hinds and Jenny Fleming (2008) "Encouraging public $\mathrm{c}$ ooperation an $\mathrm{ds}$ upport $\mathrm{f}$ or $\mathrm{p}$ olice". Policing \& Society. 18(2): 136-155. http://dx.doi.org/10.1080/10439460802008660

Oliver, William M. ( 2006) Homeland Security for Policing. New Jersey: Pearson Prentice Hall.

Poynting, S cott a nd V ictoria Mason ( 2006) " Tolerance, f reedom, justice an d pe ace? - Britain, A ustralia and anti-Muslim racisms since $11^{\text {th }}$ September 2001". Journal of Intercultural Studies. 27(4): 365-392. http://dx.doi.org/10.1080/07256860600934973

Raco, Mike ( 2003) " Governmentality, s ubject-building, a nd t he discourses a nd practices of $d$ evolution i $\mathrm{nt}$ he $U$ K". Transactions of the Institute of British Geographers. 28: 7595.

http://dx.doi.org/10.1111/1475-5661.00078

Ranstorp, Magnus a nd J osefine D os S antos ( 2009) Hot mot demokrati och värdegrund - en lägesbild från Malmö. Stockholm: The Military College: Centrum för Asymmetriska Hot och Terrorismstudier (CATS).

Rose, N iklolas ( 1999) Powers of Freedom Reframing Political Thought. Cambridge: Cambridge University Press. http://dx.doi.org/10.1017/CBO9780511488856

Sedgwick, Mark (2010) "The Concept of R adicalization as a S ource of C onfusion". Terrorism and Political Violence. 22(4): 47 9494. http://dx.doi.org/10.1080/09546553.2010.491009
Sharp, D ouglas and S usie Atherton (2007) "To Serve and Protect?" British Journal of Criminology. 47(2): 746-763. http://dx.doi.org/10.1093/bjc/azm024

Sindall, Katy, Patrick S turgis and W ill J ennings ( 2012) " Public Confidence in the P olice-A Time-Series A nalysis". British Journal of Criminology. Advanced access published June 1, 2012.

Skogan, Wesley G. (2006) "Asymmetry in the Impact of Encounters with Police". Policing \& Society. 16(2): 99-126. http://dx.doi.org/10.1080/10439460600662098

Skogan, W esley G. a nd K athleen F rydl (eds) (2004) Fairness and Effectiveness in Policing: The Evidence. Washington, DC: National Academies.

Spalek, B asia, S , E I-Awa, Laura Z ahra McDonald a nd R obert Lampert ( 2009) Policy-Muslim Engagement and Partnerships for the Purposes of Counter-Terrorism: An Examination. Birmingham: University of Birmingham.

Spencer, A. Be njamin a nd Michael H ough (2000) "A ttitudes of People from Minority Ethnic Communities Towards a Career in the P olice S ervice". Home Office Policing and Reducing Crime Unit Series Paper 121. London: Home Office.

Swedish S ecurity Se rvice $(2$ 010) Violence-promoting Islamist extremism in Sweden. The report is available for download from www.sakerhetspolisen.se

Taylor, M ichael (2007) "Community P articipation in t he R eal W orld: Opportunities a nd Pi tfalls i n Ne w G overnance Sp aces". Urban Studies. 44(2): 297-317. http://dx.doi.org/10.1080/00420980601074987

Thomas, $P$ aul (2010) “Failed a nd F riendless: T he U K's 'P reventing Violent E xtremism' P rogramme". British Journal of Politics and International Relations. 12(3): 442-458. http://dx.doi.org/10.1111/j.1467-856X.2010.00422.x

Tyler, T om R. (2 006) Why People Obey the Law. Princeton, $\mathrm{N} \mathrm{J}$ Princeton University Press.

Tyler, Tom R., Stephen Sc hulhofer a nd Az iz Z. Hu q (2 010) "Legitimacy an $d D$ eterrence $E$ ffects in $C$ ounterterrorism Policing: A Study of Mu slim A mericans". Law \& Society Review. 44(2): 365-401. http://dx.doi.org/10.1111/j.1540-5893.2010.00405.x

Waddington, P. A. J. (1999) Policing Citizens: Authority and Rights. London: UCL Press.

Received on 01-07-2012

Accepted on 25-10-2012

Published on 02-11-2012

DOI: http://dx.doi.org/10.6000/1929-4409.2012.01.11

(c) 2012 Abby Peterson; Licensee Lifescience Global.

This is an open ac cess ar ticle I icensed un der the t erms of $\mathrm{t}$ he $\mathrm{Cr}$ eative Com mons At tribution Non -Commercial Li cense (http://creativecommons.org/licenses/by-nc/3.0/) which permits unrestricted, non-commercial use, distribution and reproduction in any medium, provided the work is properly cited. 